\title{
Farmers who don't farm: The curious rise of the zero-sales farmer
}

\author{
Nathan A. Rosenberg * \\ University of Arkansas School of Law
}

\begin{abstract}
Submitted June 8, 2017 / Revised July 27, September 14, and September 15, 2017 /
Accepted September 16, 2017 / Published online October 26, 2017

Citation: Rosenberg, N. A. (2017). Farmers who don't farm: The curious rise of the zero-sales farmer. Journal of Agriculture, Food Systems, and Community Development.

Advance online publication. http://dx.doi.org/10.5304/jafscd.2017.074.005

Copyright (C) 2017 by New Leaf Associates, Inc.
\end{abstract}

\begin{abstract}
While researchers have extensively studied the growth in the number of small farms between 1982 and 2012 reported in the Census of Agriculture (COA), there has been little discussion of trends among farm operators who do not sell any agricultural products. Using previously unreleased COA data collected between 1982 and 2012, this research empirically examines these "zero-sales farmers" for the first time. There was a large increase in the number of zero-sales farmers from 104,000 in 1982 to 466,000 in 2012, as well as a remarkable rise in their share of the farming population, from 5 percent in 1982 to 22 percent in 2012. Women and minority farmers were disproportionately likely to be zero-sales operators: at least 30 percent of women, Native American, and black farmers reported no sales in 2012. Older and beginning farmers were also more likely to report zero sales in 2012 than younger and experienced
\end{abstract}

\footnotetext{
* Nathan A. Rosenberg, Graduate Program in Agricultural and Food Law, University of Arkansas School of Law; narosenb@uark.edu
}

ones, respectively. Zero-sales farmers dramatically influenced recent census data on farm income, farm size, and operator age, among other results, due to their substantial share of the overall population. In order to effectively utilize COA data, practitioners, policymakers, and researchers should include zero-sales farms in their analyses. There are several steps the U.S. Department of Agriculture (USDA) can take to make information about zerosales farmers more readily available and widely understood, such as introducing a zero-sales category in the census results.

\section{Keywords}

Agriculture; Census; Census of Agriculture; Farmers; Women Farmers; Beginning Farmers; Black Farmers; African American Farmers; Small Farms; Hobby Farms; Zero Sales

\section{Introduction}

The verb "farm" has long been associated with commercial activity. When the word first appeared in writing in the $15^{\text {th }}$ and $16^{\text {th }}$ centuries, it meant to acquire the rights to something temporarily_often 
but not exclusively land-for a fixed payment or, inversely, to assign one's property rights to another temporarily in exchange for a fixed payment, a meaning which has survived in the contemporary phrase "to farm out" (Oxford English Dictionary Online, 2017). Thus, when Richard II says that he is "enforc'd to farm our royal realm" to raise revenue in Shakespeare's King Richard the Second (Shakespeare, 1623/2012, 1.4.45), he means that he must rent or lease out the land, not that he must use it for agricultural production (Oxford English Living Dictionaries Online, n. d.). It was not until the early $19^{\text {th }}$ century that the word began to be used in recorded speech to refer to the cultivation of one's own land (OELD Online, n. d.).

Today, the Oxford American College Dictionary defines the verb "farm" as to "make one's living by growing crops or keeping livestock" (OELD Online, n.d.). While there is widespread awareness that many farmers today cannot or do not make a living from farming, it is still generally regarded as an act conducted for income. The Census of Agriculture (COA) appears to adopt this view, defining "farm" as "any place from which [US] $\$ 1,000$ or more of agricultural products were produced and sold, or normally would have been sold, during the year" (USDA, National Agricultural Statistics Service [USDA NASS], 2014a, Appendix A, 1). In recent years, however, after significant changes in COA methodology and implementation, the census has reported rapid increases in the number of zero-sales farms-farms that do not sell any agricultural products.

Conducted every five years, the COA is the most comprehensive government survey of any industry in the country. It is used by policymakers, advocacy organizations, academics, and others to understand economic and demographic characteristics of the country's farms, and to develop, implement, and evaluate programs and policies. Despite its prominence, a number of researchers have argued that COA counts of minority, women, and small-scale farmers are inaccurate. An analysis of Georgia tax digests, which provide a more complete account of land ownership than the COA, estimated that the 1920 census undercounted black-owned farmland in Georgia by about 27 percent and the 1959 census by about 49 percent
(Fisher, 1978). Spot checks made in North Carolina and Mississippi after the 1969 COA suggested that the census may have undercounted black-owned farmland by as much as 30 percent (Salamon, 1976). A study of black farmers in a Mississippi Delta county concluded that while the 1997 COA was more accurate than previous censuses, it nonetheless excluded 27 percent of the black farmers surveyed in the study because they sold less than US $\$ 1,000$ in agricultural products and thus did not meet the COA definition of farmer (Wood \& Gilbert, 2000). While most studies of undercounting are of black farmers, researchers have also found that women and other minority farmers have been undercounted. Until 2007, the COA counted all farms within each Native American reservation as a single farm, which led to severe undercounts (Bartecchi, 2009; USDA NASS, 2009). ${ }^{1}$ Women operators are disproportionately more likely to operate small-scale farms (Sachs, Barbercheck, Braiser, Kiernan, \& Terman, 2016), which has contributed to their being undercounted in the COA.

The COA has become more accurate in recent years, but this has masked real trends in the number of farms. When the USDA statistical division, the National Agricultural Statistics Service (NASS), replaced the Census Bureau as the administrator of the COA in 1997, the survey became more accurate (Gilbert, Sharp, \& Felin, 2002). Gilbert, Sharp, and Felin argue that this improved accuracy created a "false "trend," in which the number of black farmers appeared to stabilize or even increase, although the actual number likely decreased in the 1990s (Gilbert et al., 2002, p. 5). Changes made to COA sampling procedures in 2002 increased the number of small-scale farms (as measured by sales) reported in the census, skewing COA averages (Duffy, 2008). As discussed below, changes to the COA adjustment methodology were also implemented in 2002, and then again in 2012, further

\footnotetext{
${ }^{1}$ USDA conducted a pilot project during the 2002 COA to collect and publish data on individual farms and ranches on Native American reservations in Montana, North Dakota, and South Dakota (USDA NASS, 2004). Data on farms and ranches on reservations in other states were not collected, however.
} 
increasing the number of minority, women, and small-scale farmers reported by the census. While Gilbert, Sharp, and Felin limited their discussion to black farmers, the same "false "trend" appears to exist for other groups disproportionately likely to operate small-scale farms. A 2013 USDA report on women farmers compared COA data from 1982 and 2007 and found that zero-sales farms had increased fivefold - almost twice as fast as any other sales class during that period (Hoppe \& Korb, 2013). The authors also found that almost 60 percent of the increase in women farmers between 1982 and 2007 was due to the growth of zero-sales farms (Hoppe \& Korb, 2013).

This article builds on previous research by demonstrating the important role that zero-sales farms have played in recent COA trends. The rapid growth of zero-sales farms counted in the census has had a sizable impact on COA results, particularly on income averages, and on data on women and minority farmers. Prior to this article, however, data on zero-sales farmers were generally unavailable, making it difficult to assess the impact of those farms on census results. This article provides an in-depth evaluation of data on zero-sales farms for the first time.

\section{Data Sources}

After initially withholding the data due to confidentiality concerns, NASS provided the author with the total number of principal operators reporting zero sales for each of the seven censuses conducted between 1982 and 2012. In addition, NASS released data to the author from the 2012 COA on the following characteristics of principal operators with zero sales: race, ethnicity, and gender identity; age; and years of operator experience. ${ }^{2}$

A literature review found that the USDA has only released data on zero-sales farms twice prior to this article. A 1951 USDA Bureau of Agricultural Economics paper on operator income included the number of zero-sales farms counted in the $1945 \mathrm{COA}$ and a smaller survey conducted in 1947 (Koffsky \& Lear, 1951). Its results are

\footnotetext{
2 The data are available from the author by request. They can also be retrieved from the NASS Data Lab by requesting special tabulations 23377 and 23378.
}

briefly discussed below. As mentioned above, a 2013 report by the successor to the Bureau of Agricultural Economics, the USDA Economic Research Service, also included data on the number of zero-sales farms by gender in the 1982 and 2007 censuses (Hoppe \& Korb, 2013).

\section{Results}

The following section shows the total number of principal operators with zero sales for each COA between 1982 and 2012, and discusses how changes in the COA contributed to the recent rise of zero-sales operators, with an analysis of demographic characteristics of zero-sales operators in the 2012 COA across the three broad categories stated above.

Historical Trends: Between 1982 and 2012, the number of principal operators with zero sales rose considerably, as did their share of the farming population. A 1951 Bureau of Agricultural Economics paper on operator income, which included the percentage of farms reporting zero sales in 1945 and 1946, found that the share of principal operators in the COA with zero sales was much lower in the mid-20 $0^{\text {th }}$ century than it is today. In 1945, the first year for which data are available, zero-sales farmers accounted for 9 percent of all farmers (Koffsky \& Lear, 1951). A follow-up sampling survey conducted by the Bureau of Agricultural Economics in January of 1947 found that 7.4 percent of farmers reported zero sales in 1946 (Koffsky \& Lear, 1951). Although changes in sample size and methodology may account for some of the difference between the 1945 and 1946 results, the number of zero-sales farms reported in the 1945 COA may have also been abnormally high due to the wartime exodus of farmworkers and farmers into the military and industrial front (Carpenter, 1997).

In 1982, the next year for which data are available, zero-sales farmers made up 5 percent of all operators. Their share of the farming population changed little over the next 10 years: the 1992 COA reported 108,000 zero-sales operators, making up almost 6 percent of the total. This share rose to 9 percent in 1997, however, and by 2002, the COA included 449,000 zero-sales operators21 percent of the total farming population. As 
shown in Figure 1, the censuses in 2007 and 2012 reported similar totals. The 2012 COA reported 466,000 zero-sales operators, which accounted for 22 percent of all principal operators.

The dramatic increase in zero-sales operators is due in part to changes made to the COA's adjustment methodology beginning in 2002. In contrast to decennial census results, COA data are adjusted after the enumerative count. The USDA uses sampling surveys and other methods to establish estimates on census-eligible properties that were either not counted or miscounted, and then adjusts the data accordingly.

Prior to the 2002 COA, the USDA only adjusted data for nonresponses. The agency used databases, surveys, and, occasionally, telephone calls and in-person visits to estimate the characteristics of farm operators that failed to return census forms (USDA, NASS, 1999, Appendix C). These estimates were then used to modify collected data, increasing COA accuracy. As a result, a significant number of the farms reported in the census results never actually filled out a census form. In 1997, for example, 12 percent of the farms included in the final census report were added to adjust for nonresponses (USDA NASS, 1999, Appendix C).

The USDA added a new element to their adjustment methodology for the 2002 COA. In addition to accounting for nonresponses, the USDA began making "coverage adjustments"adjustments intended to account for farms it had missed (USDA NASS, 2004, Appendix C). ${ }^{3}$ About 30 percent of the farms in the $2002 \mathrm{COA}$ were added in the adjustment phase: 12 percent for nonresponses and 18 percent for the coverage adjustment (USDA NASS, 2004, Appendix C). Similarly, 31 percent of the farms in the 2007 COA were added in the adjustment phase (USDA NASS, 2009, Appendix A). In 2012, the USDA added a third component to the adjustment phase: misclassification. The misclassification adjustment

\footnotetext{
${ }^{3}$ The term "coverage adjustment" can refer to adjustments for various things, such as overcoverage, undercoverage, and errors. I follow NASS's practice here of using the term to refer to adjustment for farms that were not counted in the census but should have been.
}

modifies the data for properties that were mistakenly classified as farms or nonfarms (USDA NASS, 2014a, Appendix A). As a result, the percentage of farms reported in the COA that was due to adjustments rose to 35 percent, with 16 percent of the total added to account for nonresponses, 12 percent from the coverage adjustment, and 6 percent due to misclassification (USDA NASS, 2014a, Appendix A).

As Figure 1 demonstrates, these COA changes coincided with a massive increase in the number of principal operators reporting zero sales. In 2002, when the coverage adjustment was added, the number of zero-sales operators jumped 160 percent from the previous COA in 1997. While we do not know exactly how many of the 277,000 "new" zero-sales operators reported in 2002 were added due to the coverage adjustment-and will not know, unless the USDA releases these data-we do have such data for operators with sales below US $\$ 1,000$. As a result, we can calculate how many were added due to changes in adjustment methodology. This is significant since the $<$ US $\$ 1,000$ sales category largely comprises principal operators with zero sales: almost 80 percent of the farmers in this category were zero-sales operators in 2002.

Figure 2 shows the total number of principal operators with sales below US $\$ 1,000$ from 1982 to 2002. Then, from 2002 to 2012, it shows the number of principal operators with sales below US $\$ 1,000$ both with the coverage adjustment and without it (operators added due to the misclassification adjustment are included in the coverage adjustment category). As Figure 2 indicates, the number of principal operators in the $<$ US $\$ 1,000$ sales category would have increased considerably regardless of whether the coverage adjustment was added. In 2002, for example, there would have been an additional 107,000 principal operators even without the coverage adjustment. Thus, while coverage adjustment explains much of the increase in farms with sales below US $\$ 1,000$ - up to 64 percent of the category's growth in 2002 - it was not the only factor. Other possible factors are discussed in the subsequent section.

Race, Ethnicity, and Gender: In 2012, zero-sales operators were disproportionately likely to be minority and women. Among the racial and ethnic 
Figure 1. Number of Principal Operators with Zero Sales, 1982-2012

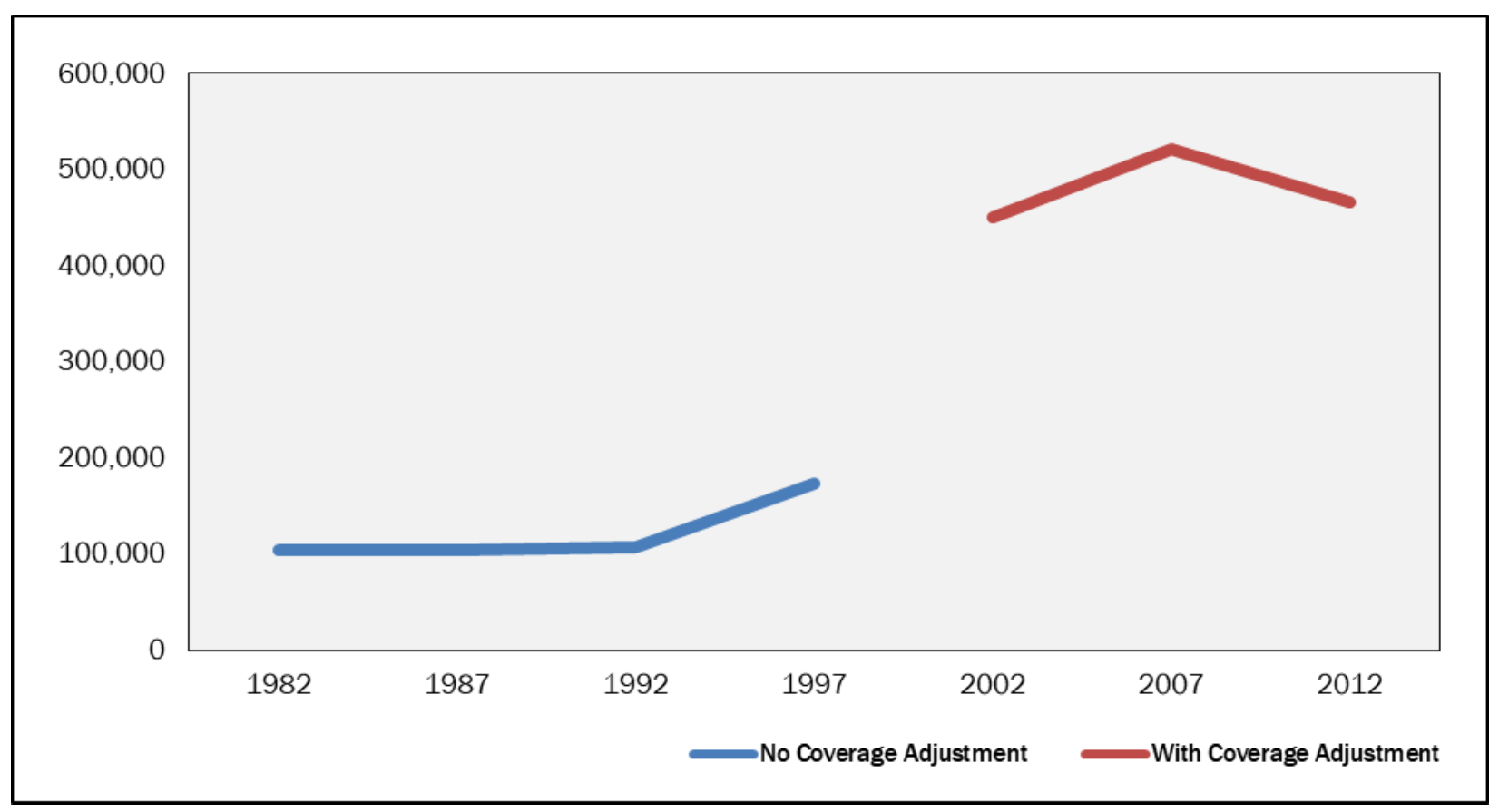

Figure 2. Number of Principal Operators with Sales Below US\$1,000, 1982-2012

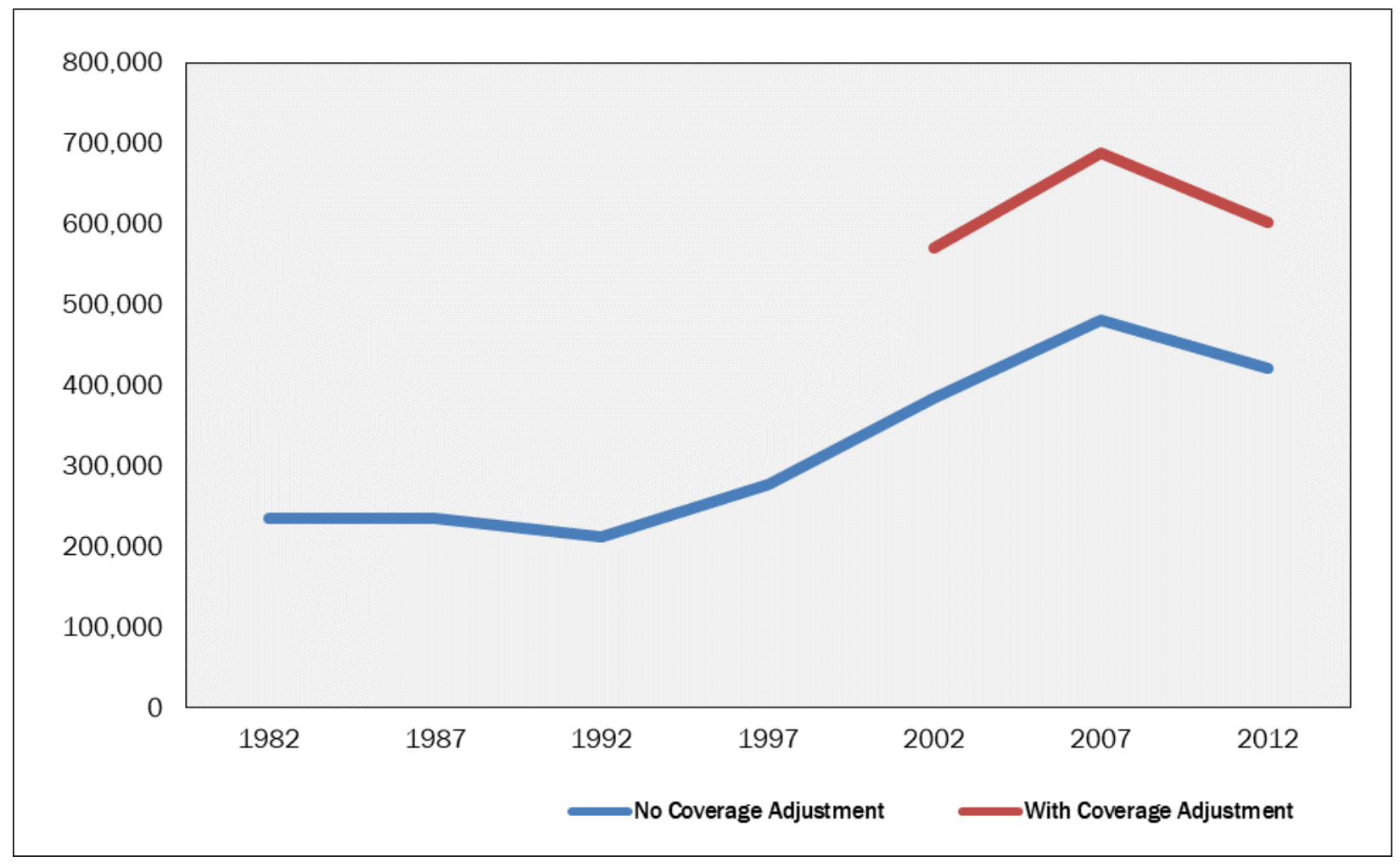


groups included in the COA, Native Americans were the most likely to be zero-sales operators (32\%), followed by blacks (30\%), Hispanics (26\%), operators reporting more than one race $(23 \%)$, and whites $(22 \%)$ (Table 1). ${ }^{4}$ A significant share of Pacific Islander (24\%) and Asian (12\%) principal operators were also classified as zero-sales operators; however, there were too few principal operators from each group in the COA for the results to be statistically reliable. Among all the ethnic, racial, and gender groups included in the $\mathrm{COA}$, women principal operators were the most likely to report zero sales $(35 \%)$, while male principal operators were the least likely $(20 \%)$.

Age: The share of principal operators reporting zero sales rises dramatically with age (see Table 2). The percentage of zero-sales operators in the oldest age group (29\%), for example, was more than twice the percentage of zero-sales operators in each of the two youngest age groups $(13 \%)$.

Years of Experience: Beginning farmers were slightly more likely to report zero sales than principal operators with a decade or more of experience. Approximately 24 percent of principal operators with less than 10 years of experience on any farm had zero sales (Table 3). This was true

${ }^{4}$ Although the COA asks farm operators if they are of "Spanish, Hispanic, or Latino origin," it does not treat Hispanic or Latino as a racial category. As a result, Hispanic farmers are identified as multiracial, black, white, or any of the other four other racial categories in the COA in addition to being categorized as Hispanic. See USDA, National Agricultural Statistics Service (2014a, Appendix B). Gender, 2012 2012
Table. 1. Principal Operators with Zero Sales by Race, Ethnicity, and

\begin{tabular}{lcc}
\hline Race, Ethnicity, or Gender & $\begin{array}{c}\text { Number of Principal } \\
\text { Operators with Zero Sales }\end{array}$ & $\begin{array}{c}\text { Percentage of Principal } \\
\text { Operators with Zero Sales }\end{array}$ \\
\hline Black & 10,042 & $30 \%$ \\
\hline Hispanic & 17,230 & $26 \%$ \\
\hline Multi-Racial & 2,322 & $23 \%$ \\
\hline Native American & 12,131 & $32 \%$ \\
\hline White & 439,096 & $22 \%$ \\
\hline Female & 100,847 & $35 \%$ \\
\hline Male & 364,791 & $20 \%$ \\
\hline Total & 465,638 & $22 \%$ \\
\hline
\end{tabular}

Table 2. Principal Operators with Zero Sales by Age, 2012

\begin{tabular}{lcc}
\hline Age Group & $\begin{array}{c}\text { Number of Principal } \\
\text { Operators with Zero Sales }\end{array}$ & $\begin{array}{c}\text { Percentage of Principal } \\
\text { Operators with Zero Sales }\end{array}$ \\
\hline Under age 25 & 1,391 & $13 \%$ \\
\hline Ages 25-34 & 13,968 & $13 \%$ \\
\hline Ages 35-44 & 37,487 & $18 \%$ \\
\hline Ages 45-54 & 94,363 & $20 \%$ \\
\hline Ages 55-64 & 134,757 & $22 \%$ \\
\hline Ages 65-74 & 109,001 & $25 \%$ \\
\hline 75 years and over & 74,671 & $29 \%$ \\
\hline
\end{tabular}

Table 3. Principal Operators with Zero Sales by Years of Experience,

\begin{tabular}{lcc}
\hline $\begin{array}{l}\text { Years of Experience } \\
\text { Operating Any Farm }\end{array}$ & $\begin{array}{c}\text { Number of Principal } \\
\text { Operators with Zero Sales }\end{array}$ & $\begin{array}{c}\text { Percentage of Principal } \\
\text { Operators with Zero Sales }\end{array}$ \\
\hline Under 5 years & 31,415 & $24 \%$ \\
\hline 5 to 9 years & 60,756 & $24 \%$ \\
\hline 10 years or more & 373,467 & $22 \%$ \\
\hline
\end{tabular}

both for principal operators who began farming after the 2007 COA (those with under five years of experience) and for principal operators who began farming between the 2002 and 2007 censuses (those with five to nine years of experience). By contrast, 22 percent of farmers with 10 years or more of experience reported zero sales.

\section{Conclusions}

The dramatic growth of zero-sales farms reported in the COA has several important implications. 
Practitioners, researchers, and policymakers should consider the influence of zero-sales farms on any COA data before using it. Programs and policies often target farmers who participate in commercial markets, yet rely on data with zero-sales farmswhich do not participate in agricultural marketsto evaluate their effectiveness. This may not have been a critical issue in 1982 when zero-sales farms accounted for only 5 percent of the total, but today, when they compose 22 percent of all farms, their inclusion has a substantial impact on important quantitative indicators, such as median farm income.

Zero-sales farms have a particularly significant impact on data regarding minority, women, and beginning farmers, since farmers in these groups are disproportionately likely to be zero-sales operators. In particular, claims that the numbers of minority, women, and beginning farmers have risen since 1997, which are commonly made by the USDA, journalists, and researchers alike (e.g., Harvey, 2016; Raftery, 2011; Sachs et al., 2016; USDA NASS, 2014b) should be re-examined in light of these new data. Further research will be needed to clarify the extent to which COA results for these groups have been affected by changes in COA methodology and implementation, as well as the rise of zero-sales farms.

The ubiquity of zero-sales farms also calls into question the widespread assumption that most small farms either compete with larger-scale farms or would do so given sufficient resources (e.g., Moyer, 2015; Smith, 2014). While undoubtedly some small farms participate in the same markets as larger-scale farms, almost 40 percent of small farms do not participate in any commercial markets for agricultural products, despite USDA data showing that, on average, small farm households have high levels of wealth (even when farm assets are excluded from the total) and low levels of debt (USDA, Economic Research Service, 2016). Further research should examine the extent to which zero-sales operators engage in agricultural production, their motivations for doing so, and their ability to access the capital necessary to operate a commercial farm.

As discussed above, changes in COA methodology likely only account for about two-thirds
(64\%) of the rise in zero-sales operators since 1997. Research will be needed to identify other possible factors contributing to the rise, such as shifts in land use and changing USDA practices, including its census outreach efforts.

Finally, the USDA should consider changing its data collection and reporting practices in view of the major role that zero-sales farms play in the U.S. agricultural landscape. Among other actions, the USDA could release additional information about its system for classifying properties with zero sales as farms, ${ }^{5}$ include additional questions in the COA on operator goals and household finances, and introduce a zero-sales category in the census results. ${ }^{6}$ Farms that do not sell products nevertheless can provide their communities with significant environmental, educational, and recreational benefits, among other contributions, thus meriting their inclusion in the COA. By gathering and sharing additional information about these operations, the USDA will allow policymakers, researchers, and practitioners to better understand their distinctive needs, characteristics, and services.

\section{Acknowledgments}

The author wishes to thank Bryce Stucki and the JAFSCD reviewers for their comments.

\footnotetext{
${ }^{5}$ While the USDA definition of a farm has been in place since 1975 , it gives the agency significant leeway in interpreting the requirement that a place "sold or normally would have sold" at least US $\$ 1,000$ of agricultural goods to qualify as a farm. The USDA currently considers properties to meet this requirement if they demonstrate the potential to produce US $\$ 1,000$ in sales from agricultural products, even if they are not actively engaged in agricultural production (O’Donoghue, Hoppe, Banker, \& Korb, 2009).

${ }^{6}$ There are currently 15 different sales categories in the COA, ranging from less than US $\$ 1,000$ agricultural products sold to US $\$ 5,000,000$ or more. If adopted as a sales category, zerosales would be the largest in the census and more than twice the size of the next largest category. See USDA, NASS (2014a, Table 2).
} 


\section{References}

Bartecchi, D. (2009, November 4). USDA misrepresents situation of Native American farmers. Village Earth [Blog post]. Retrieved from https://www.villageearth.org/pages/global-affiliate-network/projects-pineridge-reservation/usdamisrepresents-situation-of-native-american-farmers

Carpenter, S. A. (1997). "Regular farm girl": The women's land army in World War II. Agricultural History, 71(2), 162-185. Retrieved from http://www.jstor.org/stable/3744245

Duffy, M. (2008). Appendix: The changing status of farms and ranches of the middle. In T. A. Lyson, G. W. Stevenson, \& R. Welsh (Eds.), Food and the mid-level farm: Renewing an agriculture of the middle (pp. 257-284). Cambridge, Massachusetts: MIT Press.

Fisher, J. S. (1978). Rural ownership of land by blacks in Georgia: 1920 and 1960. Review of Black Political Economy, 9(1), 95-107. https://doi.org/10.1007/BF02689539

Gilbert, J., Sharp, G., \& Felin, M. S. (2002). The loss and persistence of black-owned farms and farmland: A review of the literature and its implications. Southern Rural Sociology, 18(2), 1-30. http://journalofruralsocialsciences.org/pages/ Articles/SRS $\% 202002 \% 2018 / 2 /$ SRS $\% 202002 \% 2018 \% 202 \% 201-30$.pdf

Harvey, S. A. (2016, July 15). The resurgence of black farmers. Civil Eats [Online newsgroup]. Retrieved from http://civileats.com/2016/07/15/the-resurgence-of-black-farmers/

Hoppe, R. A., \& Korb, P. (2013, April). Characteristics of women farm operators and their farms (Economic Information Bulletin No. 111). Washington, D.C.: USDA, Economic Research Service. Retrieved from https://www.ers.usda.gov/publications/pub-details/?pubid $=43750$

Koffsky, N. M., \& Lear, J. E. (1951). Size distribution of farm operators' income in 1946. In Conference on Research in Income and Wealth (Eds.), Studies in income and wealth, vol.13 (pp. 220-264). New York: National Bureau of Economic Research.

Moyer, J. (2015, February 9). What nobody told me about small farming: I can't make a living. Salon [Online news and opinion group]. Retrieved from http://www.salon.com/2015/02/10/what nobody told me about small farming i cant make a living/

O’Donoghue, E. J., Hoppe, R. A., Banker, D. E., \& Korb, P. (2009, March). Exploring alternative farm definitions: Implications for agricultural statistics and program eligibility (Economic Information Bulletin No. 49). Washington, D.C.: USDA, Economic Research Service. Retrieved from https://www.ers.usda.gov/webdocs/publications/44357/9671_eib49.pdf?v=41318

Oxford English Living Dictionaries Online. (n.d.). Farm. Oxford, UK \& New York: Oxford University Press. Retrieved from https://en.oxforddictionaries.com/definition/farm

Raftery, I. (2011, March 5). In new food culture, a young generation of farmers emerges. The New York Times (p. A19). Retrieved from http://www.nytimes.com/2011/03/06/us/06farmers.html

Sachs, C. E., Barbercheck, M. E., Braiser, K., Kiernan, N. E., \& Terman, A. R. (2016). The rise of women farmers and sustainable agriculture. Iowa City: University of Iowa Press.

Salamon, L. M. (1976). Land and minority enterprise: The crisis and the opportunity. Washington, D.C.: Office of Minority Business Enterprise. Retrieved from https://eric.ed.gov/?id=ED139852

Shakespeare, W. (2012). King Richard II. (G. L. Kittredge, Ed.). Newburyport, Massachusetts: Focus Publishing. (Original work pub. 1623.)

Smith, B. (2014, August 9). Don't let your children grow up to be farmers. The New York Times (p. SR5). Retrieved from https://www.nytimes.com/2014/08/10/opinion/sunday/dont-let-your-children-grow-up-to-be-farmers.html? $\mathrm{r}=0$

U.S. Department of Agriculture, Economic Research Service [USDA ERS]. (2016). Principal farm operator household finances, by ERS farm typology [Table]. Retrieved from https://www.ers.usda.gov/webdocs/DataFiles/48870/table02.xls?v=42704

USDA, National Agricultural Statistics Service [USDA NASS]. (1999). 1997 Census of Agriculture. Retrieved from http://agcensus.mannlib.cornell.edu/AgCensus/censusParts.do?year $=1997$

USDA NASS. (2004). 2002 Census of Agriculture. Retrieved from http://agcensus.mannlib.cornell.edu/AgCensus/censusParts.do?year=2002 
USDA NASS. (2009). 2007 Census of Agriculture. Retrieved from https://www.agcensus.usda.gov/Publications/2007/

USDA NASS. (2014a). 2012 Census of Agriculture. Retrieved from https://www.agcensus.usda.gov/Publications/2012/

USDA NASS. (2014b). 2012 Census of Agriculture reveals new trends in farming [Press release]. Retrieved from https://www.agcensus.usda.gov/Newsroom/2014/05 02 2014.php

Wood, S. D., \& Gilbert, J. (2000). Returning African American farmers to the land: Recent trends and a policy rationale. Review of Black Political Economy, 27(4), 43-64. https://doi.org/10.1007/BF02717262 